\title{
Dose Load during Angiographic Procedures LAD Stenting
}

\author{
Severina Ivanova \\ Clinic “Nuclear Medicine and Metabolic Therapy”, University Hospital “St. Marina”, Varna, Bulgaria \\ Email: natasha_i@abv.bg
}

How to cite this paper: Ivanova, S. (2021) Dose Load during Angiographic Procedures LAD Stenting. Open Access Library Journal, 8: e7390

https://doi.org/10.4236/oalib.1107390

Received: April 6, 2021

Accepted: May 3, 2021

Published: May 6, 2021

Copyright (C) 2021 by author(s) and Open Access Library Inc.

This work is licensed under the Creative Commons Attribution International License (CC BY 4.0).

http://creativecommons.org/licenses/by/4.0/

\section{(c) (i) Open Access}

\begin{abstract}
Based on published dosimetric measurements, the dose load received by the interventional cardiologist from scattered X-ray radiation was assessed for an angiographic LAD stenting procedure under X-ray guidance. An angiographic X-ray system "Philips Allura Xper FD10" was used for the study. The dose assessment calculations were made for three positions of the patient table-basic, lowest and highest-and for three measurement points-"head", "gonads" and "feet", in which the received dose was measured. Due to the fact that three different projections are used during the procedure (RAO-cranial, LAO-cranial and pure Cranial), and each of them can be basic, calculations are made for each of them as a basic procedure. The obtained results show that the dose load obtained from this procedure is mainly due to the work performed in the radiographic mode of operation. In order to reduce the received dose load, it is necessary to take into account the position of the patient table during work and the use of appropriate individual radiation protection devices.
\end{abstract}

\section{Subject Areas}

Internal Medicine, Radiology \& Medical Imaging

\section{Keywords}

Angiographic X-Ray System, Dose Load, Interventional, Cardiology, Cardiology Hospital, LAD Stenting

\section{Introduction}

Life on planet Earth originated under certain conditions: nitrogen atmosphere, certain temperature, pressure, sun light etc. A necessary condition for life is the natural radiation background [1] [2]. 
The research of many scientists and the respective discoveries has led to the development of ingenious devices and modern systems that people use to improve their life [3] [4].

The discovery and use of X-rays have revolutionized human life [5] [6]. The widespread use of X-rays and other ionizing radiation leads to an increase of the radiation background of the earth. Exceeding the values of the radiation background above certain limits, leads to severe consequences for life on Earth. Radiation accidents caused by working with ionizing radiation have caused severe damage that remains for a long time [7] [8] [9].

Ionizing radiation, and in particular X-rays, are widely used in modern medicine [10] [11] [12]. Renovation and modernization of X-ray equipment is a top priority nowadays [13]

In addition to the positive side, ionizing radiation has many disadvantages. To reduce the harm caused by ionizing radiation in medicine, emphasis should be placed on raising awareness and training on how to work safely with ionizing radiation. In addition to the training of future physicians in medical universities [14] [15], periodic specialized courses have been introduced to acquire the right to work with sources of ionizing radiation [16] [17] [18].

The radiation protection of staff and the general public is of the utmost importance, as is the reduction of the dose exposure achieved by the scattered ionizing radiation during ionizing radiation procedures. Research into this regard is ongoing when working with various types of medical devices using ionizing radiation.

In two monographs [19] [20] and in a series of articles N. Ivanova et al. examined the dose load of a patient [21] and staff when working with C-arm type $\mathrm{X}$-ray equipment [22] [23] and wtih angiographic equipment [24] [25] [26].

Guo, C. et al. [27] and Alnewaini, Z. et al. [28] in their articles describe their research done with C-arm X-ray equipment, and in the articles of Sadick V. et al. [29] and Mavrikou I. et al. [30] examine the dose load of staff and patients during angiographic procedures.

\subsection{Motivation}

Our study was provoked by N. Ivanova-a lecturer at the Medical University, Varna, Bulgaria, who provided us with the data from the dose measurements made by her and her team, while working with angiographic X-ray equipment "Philips Allura Xper FD10", in the Specialized Hospital for Active Treatment in Cardiology in Varna, Bulgaria.

\subsection{Purpose of the Study}

The purpose of this article is to make calculations of the dose load received by the medical staff during the LAD stenting (stenting of the left anterior descending coronary artery) in the basic operating modes of the X-ray equipment and for three different projections used as basic. Further, on the basis of these calcu- 
lations, the dose load of the two modes of operation (radiography and fluoroscopy) of the equipment is to be compared, in the three projections (RAO-cranial, LAO-cranial and pure Cranial), used as basic projections, for three different patient table positions (lowest, highest and zero), in three measurement points ("head", "gonads" and "feet"). Based on this comparison, measures to reduce the dose load of the medical staff during the implementation of a LAD procedure are to be recommended.

\section{Study}

\subsection{Methods}

The main methodology in this study is mathematical calculations based on the values provided by dosimetric measurements [19] and comparison of the results obtained to optimize the received dose load from scattered X-rays of medical staff during the LAD stenting.

\subsection{Practical Work}

Durng the LAD stenting procedure following projections are used (Table 1). The total duration of the procedure is $45-90$ minutes, of which:

- 3 - 4 seconds AP projection-this is the starting projection.

- Work in the basic projection-30 to 60 minutes; here, each one of the three projections can be used as basic projection. The duration of pulse fluoroscopy in the basic projectioin is about 10 minutes, and that of radiographic mode is about 2 - 3 minutes.

- The duration of the non-basic projections is about 15 to 30 minutes; here the duration of the pulse fluoroscopy is about 5 minutes. Radiography is not used for the non-basic projectioins.

Due to the low dose load of the PA projection, it is not included in the general calculations as it will not significantly affect the results.

\section{Results}

Dose calculations for the different projections are given in Tables 2-4.

The results of the tables are illustrated with graphs 1,2, 3 for Table 2; graphs 4, 5, 6 for Table 3, graphs 7, 8, 9 for Table 4 and graphs 10, 11 and 12 ilustrate the summarized results for the whole procedure in the three positions of the patient table-lowest (graphs 10), highest (graphs 11) and zero (graphs 12).

For each of the comparative diagrams, the received dose in radiographic and

Table 1. Projections, used in the LAD Stenting procedure.

\begin{tabular}{cc}
\hline AP & $0^{\circ} / 0^{\circ}$ \\
RAO-cranial & $30^{\circ} / 30^{\circ}$ \\
LAO-cranial & $30^{\circ} / 30^{\circ}$ \\
Cranial & $30^{\circ}$ \\
\hline
\end{tabular}


fluoroscopic mode was calculated. For the basic projection the calculations were made for 2 and then for 3 minutes raiography. Therefore, the graphs show sectors " 2 minutes" (summation of fluoroscopy doses for the three projections used and 2 minutes radiography in the main projection) and " 3 minutes" (summation of fluoroscopy doses for the three projections used and 3 minutes radiography in the main projection).

In the studied LAD stenting procedure, all graphs show the highest dose load in graphical mode. The dose values obtained in the non-basic projections are very low and therefore the comparison will be made only for the values obtained for work in the basic projections.

When comparing Diagrams 1-3 for the lowest position of the patient table, the highest values in radiographic mode are observed in the basic projection Pure Cranial both for 2 and 3 minutes irradiation. The highest dose was measured in this position of the patient table in the measurement point "gonads" for all three basic projections. The lowest values were measured for the point "head" also for the three basic projections. When comparing the values for fluoroscopic mode, the highest values are obtained for the basic projection LAO-cranial. Here again the highest dose is obtained in the point "gonads" and the lowest-in the point "head" for all three basic projections, similar to the radiographic mode.

When comparing Diagrams 4-6 for the highest position of the patient table no projectioin with predominantly higher or lower values is observed, neither in radiographic nor in fluoroscopic mode. In the radiographic mode, the maximum of the dose values are measurd in the point "gonads" for the two basic projections: LAO-cranial and Pure Cranial. For the basic projection RAO-cranial two equal peak vlaues are observed, namely in the points "head" and "feet". The lowest values for the radiographic mode are observed in the points "head" and "feet" for two projections; LAO-cranial and Pure Cranial; for RAO-cranial the lowest value is obteined in "gonads". Comparing the dose load in the fluoroscopic mode the highest dose values are obtained for the three basic projections but in different points. In RAO-cranial-these are "head" and "feet", like in radiographic mode and in LAO-cranial only in the point "feet"; for Pure Cranial again these are "gonads" and "feet". The lowest value is obtained for the "gonads" in the basic projections LAO-cranial and Pure Cranial.

When comparing Diagrams 7-9 for the zero position of the patient table again no predominantly lower or higher values were observed in a specific measurement point. The highest value for the radiographic mode is obtained for the point "gonads" in the basic projection LAO-cranial. Comparable but lower values were obtained in the main projection RAO-cranial in the points "steps" and "gonads". The lowest values in the radiographic mode for all three projections are obtained for the measuremnet point "head". When using the fluoroscopic mode the predominantly highest value was measured for the three projections in the point "gonads", and the lowest value was measured in the point "head".

When comparing Diagrams 10-12 for the doses obtained for the whole procedure in the three different positions of the patient table, again no measurement 
Table 2. Dose received during the angiographic procedure LAD stenting by an interventional cardiologist for the lowest position of the patient table, at three points of his body.

\begin{tabular}{|c|c|c|c|c|c|}
\hline \multirow{2}{*}{ Type } & \multirow{2}{*}{ Projection } & \multirow{2}{*}{ Duration } & head & gonads & feet \\
\hline & & & \multicolumn{3}{|c|}{ Dose in $\mu \mathrm{Sv}$} \\
\hline \multirow{3}{*}{ basic } & & 3 min. graphy & 22.5 & 37.0 & 23.4 \\
\hline & RAO-cranial & 2 min. graphy & 15.0 & 25.2 & 15.6 \\
\hline & & 10 min. scopy & 3.0 & 9.0 & 9.0 \\
\hline \multirow{2}{*}{ non-bassic } & LAO-cranial & 5 min. scopy & 1.5 & 3.75 & 1.5 \\
\hline & Cranial & 5 min. scopy & 0.75 & 2.25 & 2.25 \\
\hline \multirow{2}{*}{\multicolumn{2}{|c|}{ Total dose received during the whole procedure }} & for 2 min. graphy & 20.25 & 40.20 & 28.35 \\
\hline & & for 3 min. graphy & 26.75 & 52.2 & 36.15 \\
\hline \multirow{3}{*}{ basic } & & 3 min. graphy & 22.5 & 37.8 & 23.4 \\
\hline & LAO-cranial & 2 min. graphy & 15.0 & 25.2 & 15.6 \\
\hline & & 10min. scopy & 6.0 & 15.0 & 6.0 \\
\hline \multirow{2}{*}{ non-bassic } & $R A O$-cranial & 5 min. scopy & 0.75 & 2.25 & 2.25 \\
\hline & Cranial & 5 min. scopy & 0.75 & 2.25 & 2.25 \\
\hline \multirow{2}{*}{\multicolumn{2}{|c|}{ Total dose received during the whole procedure }} & for 2 min. graphy & 21.90 & 38.25 & 30.30 \\
\hline & & for 3 min. graphy & 29.10 & 46.85 & 40.30 \\
\hline \multirow{3}{*}{ basic } & & 3 min. graphy & 25.2 & 51.3 & 33.3 \\
\hline & Cranial & 2 min. graphy & 16.8 & 34.2 & 22.2 \\
\hline & & 10 min. scopy & 3.0 & 9.0 & 9.0 \\
\hline \multirow{2}{*}{ non-bassic } & LAO-cranial & 5 min. scopy & 1.5 & 3.75 & 1.5 \\
\hline & $R A O$-cranial & 5 min. scopy & 0.75 & 2.25 & 2.25 \\
\hline \multirow{2}{*}{\multicolumn{2}{|c|}{ Total dose received during the whole procedure }} & for 2 min. graphy & 22.05 & 49.20 & 34.90 \\
\hline & & for 3 min. graphy & 30.45 & 66.3 & 46.00 \\
\hline
\end{tabular}

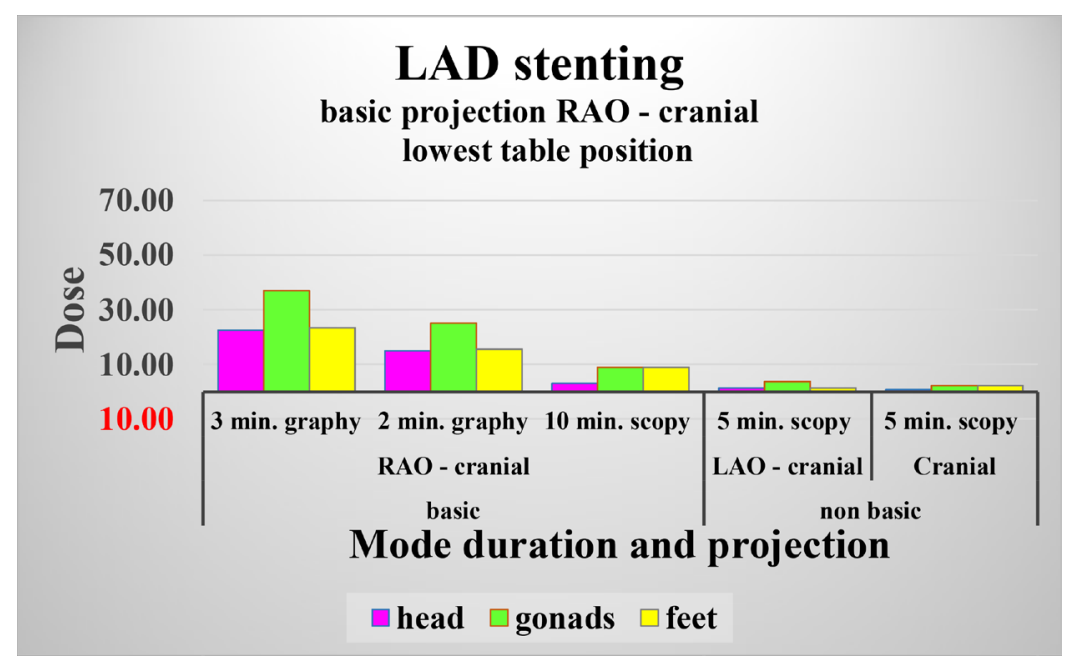

Diagram 1. Basic projection RAO cranial-lowest table position. 


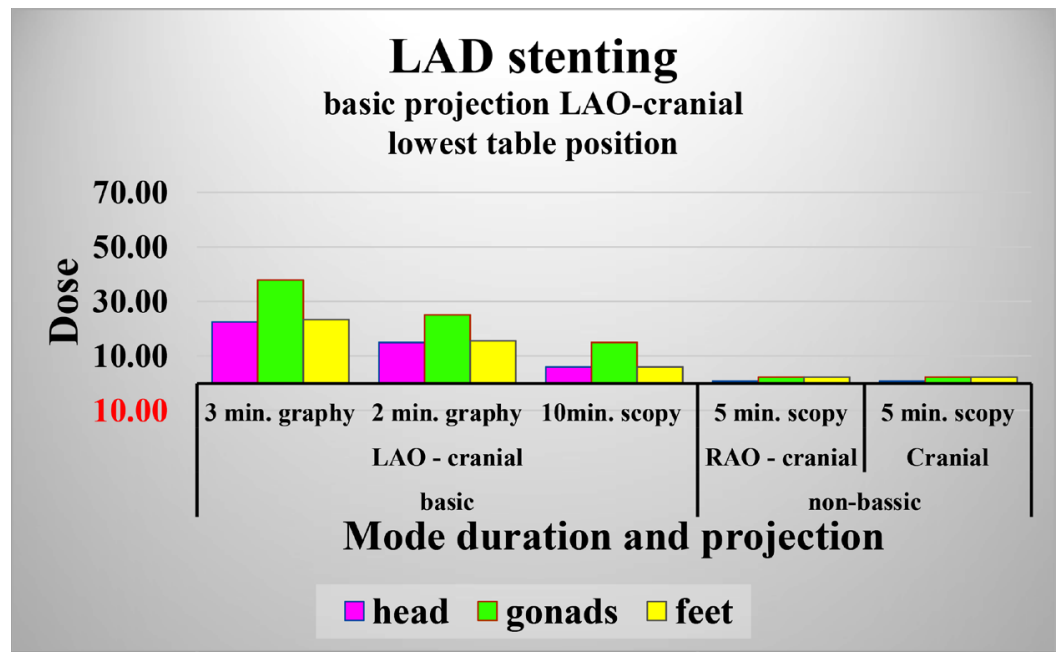

Diagram 2. Basic projection LAO cranial-lowest table position.

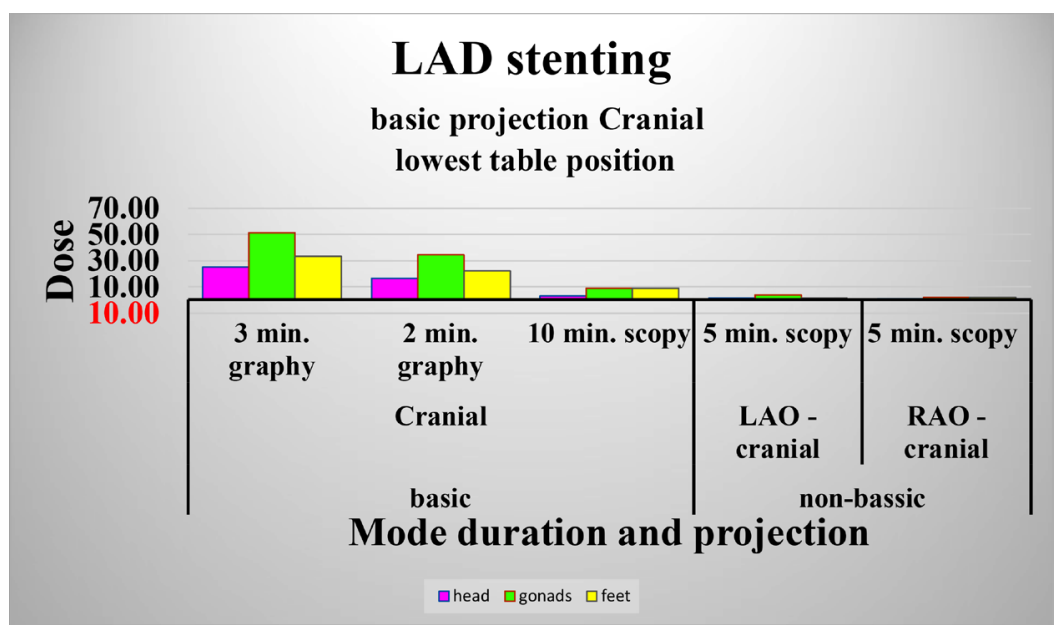

Diagram 3. Basic projection Cranial-lowest table position.

Table 3. Dose received during the angiographic procedure LAD stenting by an interventional cardiologist for the highest position of the patient table, at three points of his body.

\begin{tabular}{|c|c|c|c|c|c|}
\hline \multirow{2}{*}{ Type } & \multirow{2}{*}{ Projection } & \multirow{2}{*}{ Duration } & head & gonads & feet \\
\hline & & & \multicolumn{3}{|c|}{ Dose in $\mu \mathrm{Sv}$} \\
\hline \multirow{3}{*}{ basic } & \multirow{3}{*}{ RAO-cranial } & 3 min. graphy & 39.6 & 33.3 & 38.7 \\
\hline & & 2 min. graphy & 26.4 & 22.2 & 25.8 \\
\hline & & 10 min. scopy & 15.0 & 12.0 & 15.0 \\
\hline \multirow{2}{*}{ non-bassic } & LAO-cranial & 5 min. scopy & 0.75 & 2.25 & 3.75 \\
\hline & Cranial & 5 min. scopy & 0.75 & 3.75 & 3.75 \\
\hline \multirow{2}{*}{\multicolumn{2}{|c|}{ Total dose received during the whole procedure }} & for 2 min. graphy & 42.9 & 40.20 & 48.30 \\
\hline & & for 3 min. graphy & 56.10 & 51.30 & 61.20 \\
\hline \multirow{3}{*}{ basic } & \multirow{3}{*}{ LAO-cranial } & 3 min. graphy & 19.8 & 38.7 & 29.7 \\
\hline & & 2 min. graphy & 13.2 & 25.8 & 19.8 \\
\hline & & $10 \mathrm{~min} . \mathrm{scopy}$ & 3.0 & 9.0 & 15.0 \\
\hline
\end{tabular}




\section{Continued}

\begin{tabular}{|c|c|c|c|c|c|}
\hline \multirow{2}{*}{ non-bassic } & $R A O$-cranial & 5 min. scopy & 3.75 & 3.00 & 3.75 \\
\hline & Cranial & 5 min. scopy & 0.75 & 3.75 & 3.75 \\
\hline \multirow{2}{*}{\multicolumn{2}{|c|}{ Total dose received during the whole procedure }} & for 2 min. graphy & 20.70 & 41.55 & 42.30 \\
\hline & & for 3 min. graphy & 27.30 & 54.45 & 53.20 \\
\hline \multirow{3}{*}{ basic } & & 3 min. graphy & 23.4 & 35.1 & 30.6 \\
\hline & Cranial & 2 min. graphy & 15.6 & 23.4 & 20.4 \\
\hline & & 10 min. scopy & 3.0 & 15.0 & 15.0 \\
\hline \multirow{2}{*}{ non-bassic } & LAO-cranial & 5 min. scopy & 0.75 & 2.25 & 3.75 \\
\hline & RAO-cranial & 5 min. scopy & 3.75 & 3.00 & 375 \\
\hline \multirow{2}{*}{\multicolumn{2}{|c|}{ Total dose received during the whole procedure }} & for 2 min. graphy & 22.05 & 23.10 & 43.65 \\
\hline & & for 3 min. graphy & 30.45 & 30.90 & 55.35 \\
\hline
\end{tabular}

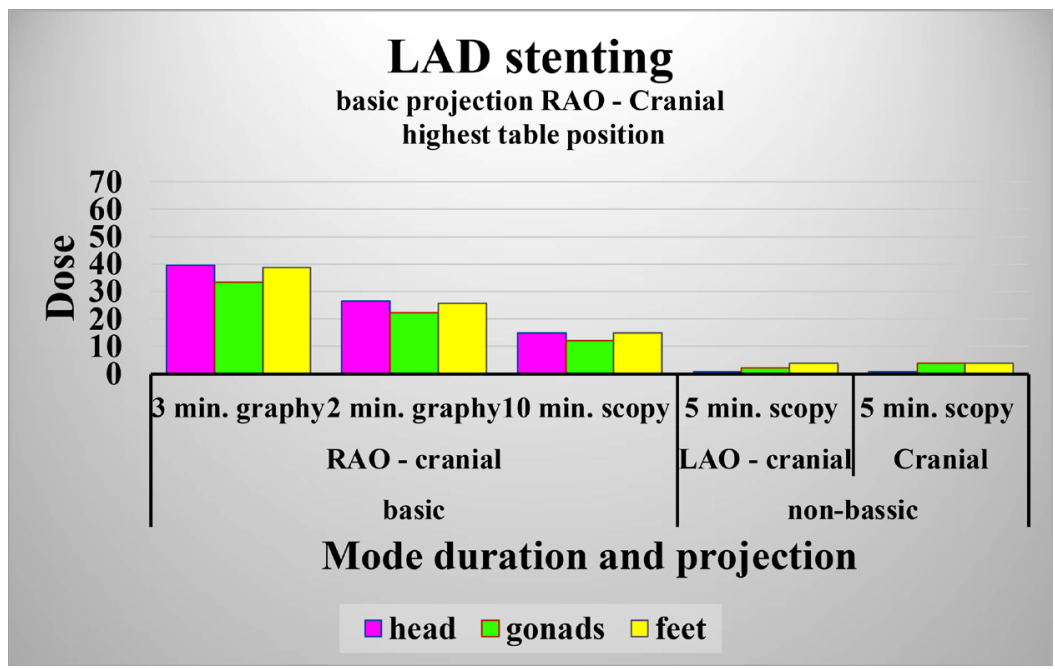

Diagram 4. Basic projection RAO-cranial-highest table position.

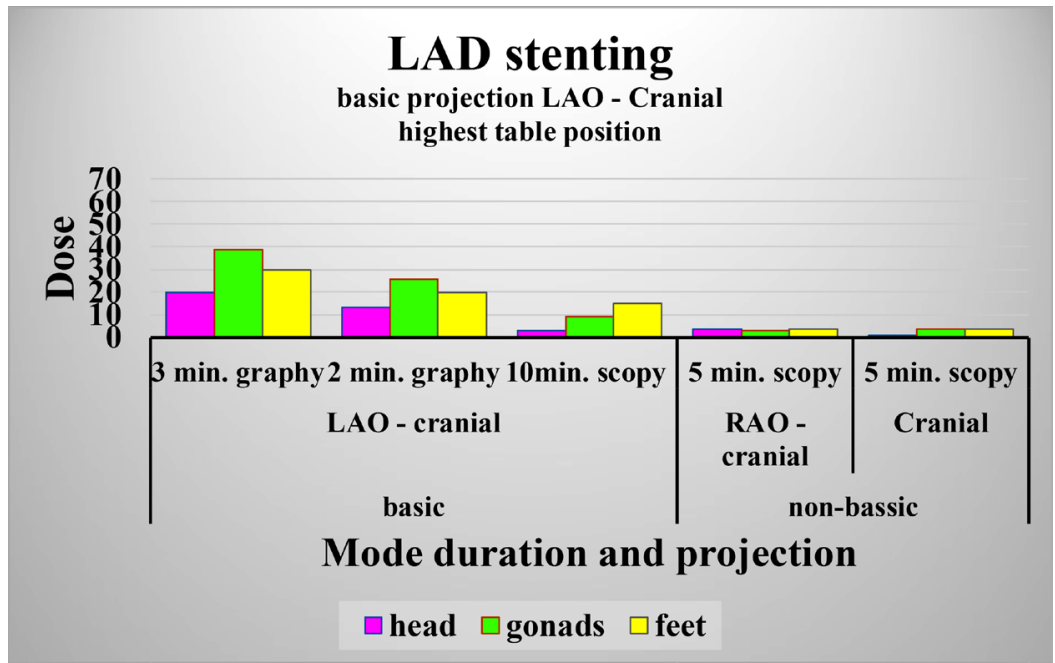

Diagram 5. Basic projection LAO cranial-highest table position. 


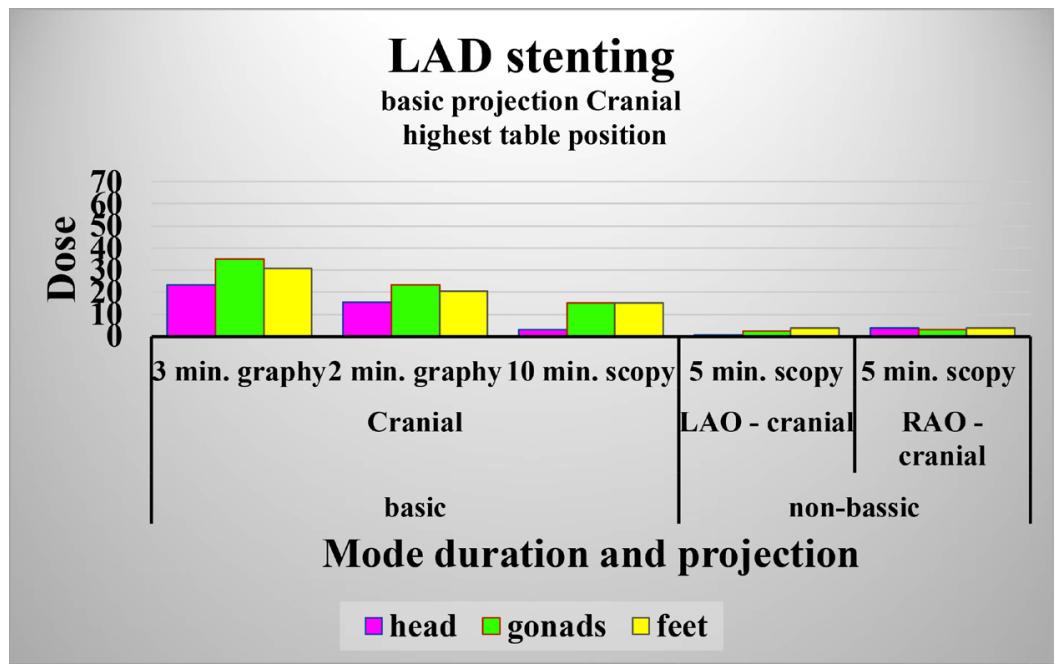

Diagram 6. Basic projection Cranial—highest table position.

Table 4. Dose received during the angiographic procedure LAD stenting by an interventional cardiologist for the zero position of the patient table, at three points of his body.

\begin{tabular}{|c|c|c|c|c|c|}
\hline \multirow{2}{*}{ Type } & \multirow{2}{*}{ Projection } & \multirow{2}{*}{ Duration } & head & gonads & feet \\
\hline & & & \multicolumn{3}{|c|}{ Dose in $\mu \mathrm{Sv}$} \\
\hline \multirow{3}{*}{ asic } & & 3 min. graphy & 23.4 & 35.1 & 36.0 \\
\hline & RAO-cranial & 2 min. graphy & 15.6 & 23.4 & 24.0 \\
\hline & & 10 min. scopy & 6.0 & 12.0 & 6.0 \\
\hline \multirow{2}{*}{ non-bassic } & $L A O$-cranial & 5 min. scopy & 0.75 & 3.75 & 1.50 \\
\hline & Cranial & 5 min. scopy & 0.75 & 3.00 & 2.25 \\
\hline \multirow{2}{*}{\multicolumn{2}{|c|}{ Total dose received during the whole procedure }} & for 2 min. graphy & 23.10 & 42.15 & 48.30 \\
\hline & & for 3 min. graphy & 30.90 & 51.30 & 53.85 \\
\hline \multirow{3}{*}{ basic } & & 3 min. graphy & 19.8 & 36.97 & 21.9 \\
\hline & LAO-cranial & 2 min. graphy & 13.2 & 24.6 & 14.4 \\
\hline & & 10 min. scopy & 3.0 & 9.0 & 15.0 \\
\hline \multirow{2}{*}{ non-bassic } & RAO-cranial & 5 min. scopy & 1.5 & 3.0 & 1.5 \\
\hline & Cranial & 5 min. scopy & 0.75 & 3.00 & 2.25 \\
\hline \multirow{2}{*}{\multicolumn{2}{|c|}{ Total dose received during the whole procedure }} & for 2 min. graphy & 18.45 & 45.60 & 24.15 \\
\hline & & for 3 min. graphy & 25.05 & 57.90 & 31.65 \\
\hline \multirow{3}{*}{ basic } & & 3 min. graphy & 18.9 & 27.9 & 28.8 \\
\hline & Cranial & 2 min. graphy & 12.6 & 18.6 & 19.2 \\
\hline & & 10 min. scopy & 3.0 & 12.0 & 9.0 \\
\hline \multirow{2}{*}{ non-bassic } & LAO-cranial & 5 min. scopy & 0.75 & 3.75 & 1.50 \\
\hline & $R A O$-cranial & 5 min. scopy & 1.5 & 3.0 & 1.5 \\
\hline \multirow{2}{*}{\multicolumn{2}{|c|}{ Total dose received during the whole procedure }} & for 2 min. graphy & 17.85 & 37.35 & 31.20 \\
\hline & & for $3 \mathrm{~min}$. graphy & 24.15 & 46.65 & 40.80 \\
\hline
\end{tabular}




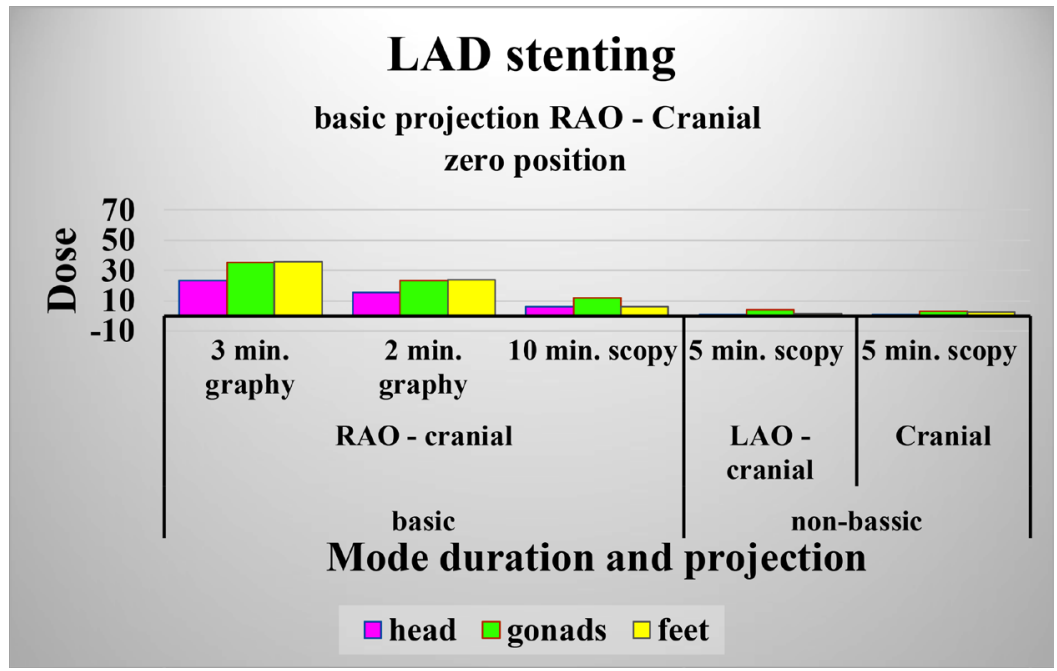

Diagram 7. Basic projection RAO_Cranial-zero table position.

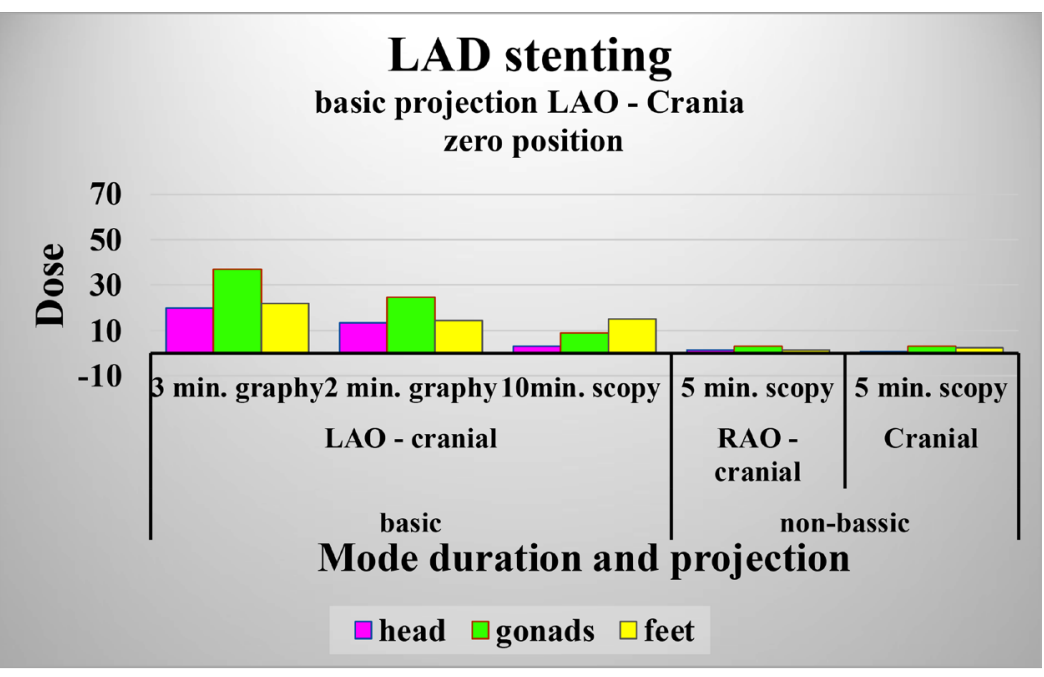

Diagram 8. Basic projection LAO cranial-zero table position.

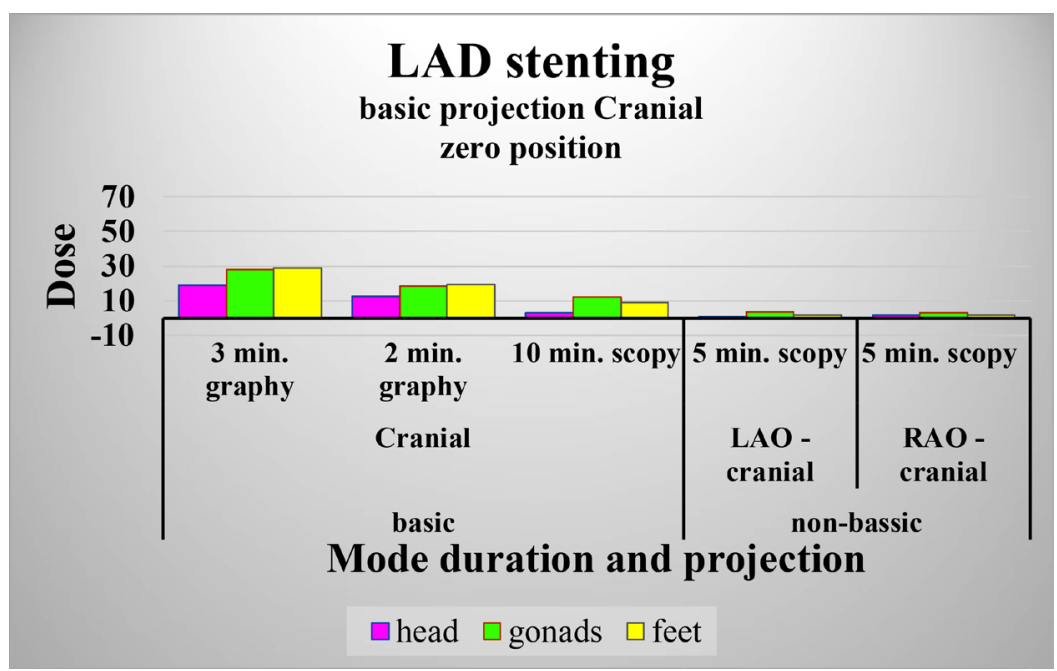

Diagram 9. Basic projection Cranial-zero table position. 


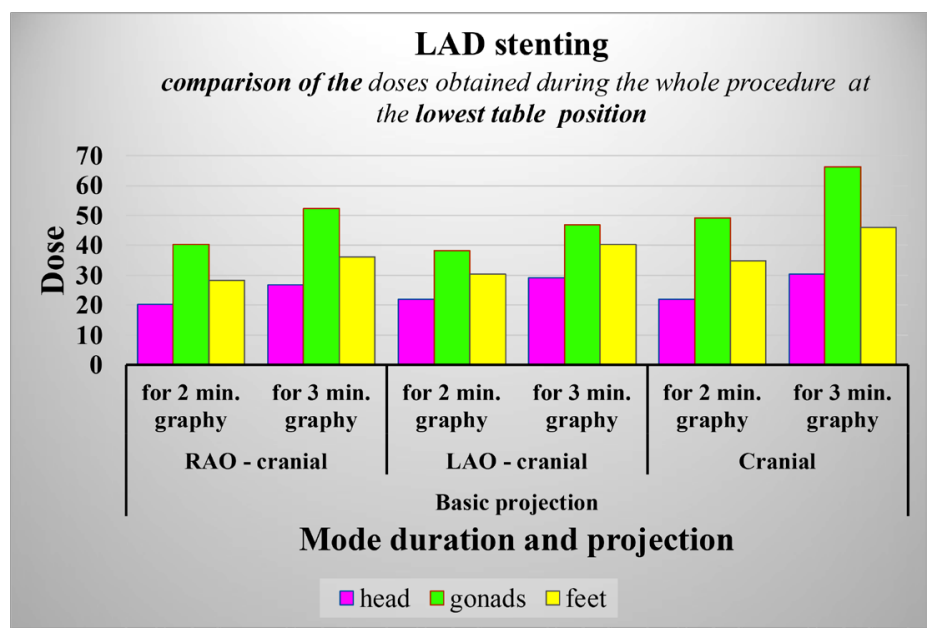

Diagram 10. Comparison of the doses obtained during the whole procedure for different basic projections at the lowest position of the patient table.

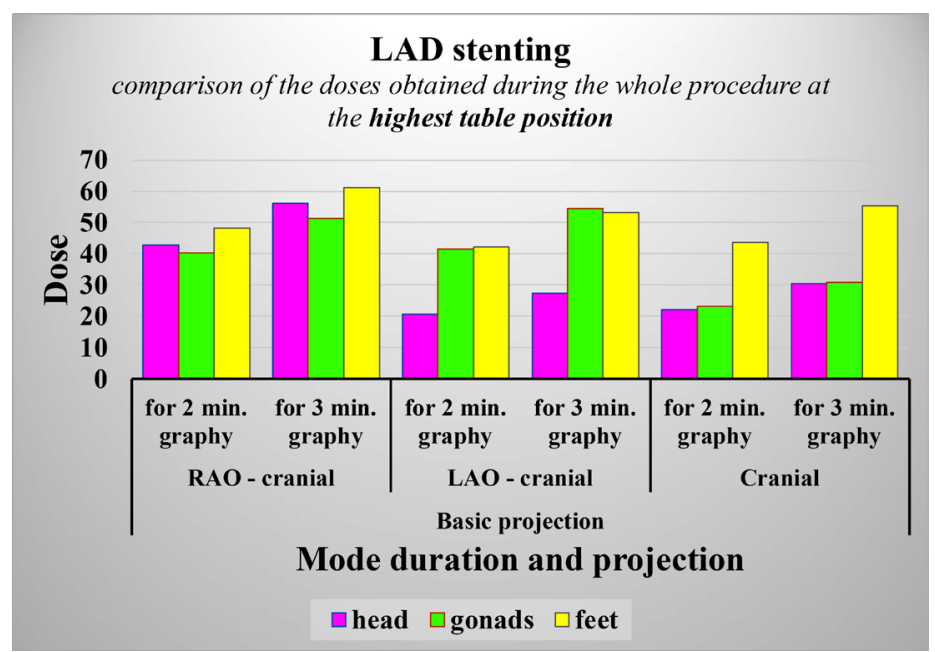

Diagram 11. Comparison of the doses obtained during the whole procedure for different basic projections at the highest position of the patient table.

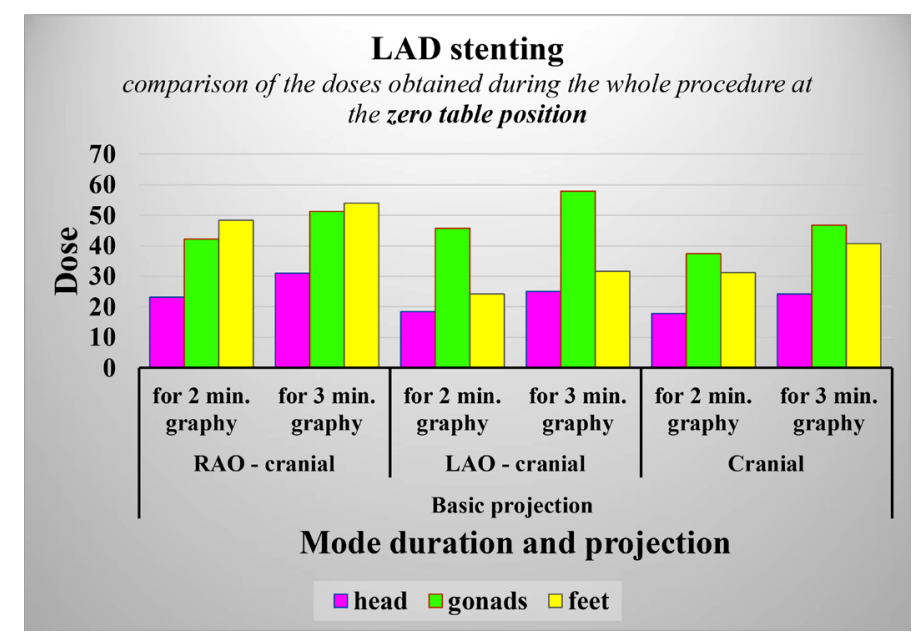

Diagram 12. Comparison of the doses obtained during the whole procedure for different basic projections at the zero position of the patient table. 
point was observed with predominantly higher or lower dose values.

In Figure 10 (lowest patient table position), predominant maximum dose values were observed at the measurement point "gonads" for all three main projections; the minimum values prevail at the measurement point "head".

At the highest position of the patient table for the different projections, maximum and minimum values are observed in different measurement points.

At the zero position of the patient table, predominantly low values are observed in the measurement point "head", analogous to the lowest position of the patient table. High values are observed in points "gonads" and "feet".

Comparing the dose values for the different basic projections from graphs 10 , 11 and 12, the maximum number of high values is observed at the main projection RAO-cranial. In the other two basic projections the number of high and low values is almost the same.

Comparison of the doses obtained by the principal interventional cardiologist, at three points of his body, for the whole LAD stenting procedure for the different basic projections and for different positions of the patient table.

\section{Conclusions}

The results of the study show that the dose load in the LAD stenting procedure is mainly due to the use of the radiographic mode of the X-ray equipment. This high value is observed although the duration of the radiographic mode is $2-3$ minutes, while the duration of the fluoroscopic mode is about 10 minutes for the basic projection and 5 minutes for non-basic projections, i.e. in total 15 minutes. The comparison of the two modes of operation shows 5 - 6 times longer duration in fluoroscopy mode compared to radiographic mode. Therefore, for this type of X-ray equipment, the use of fluoroscopic mode is safer than the radiographic one. In this sense, in order to reduce the dose load of the medical staff performing the procedure, it is necessary to reduce the duration of work in radiographic mode as much as possible. This could be achieved with appropriate training and prior accumulation of experience. According to the obtained results, the highest dose load is received in the basic projection RAO cranial. In this projection, high values are obtained at all measured points. Due to the fact that the use of a basic procedure is determined by the area of interest in the patient's body, it is not possible to reduce the number of used procedures in such a basic projection. Thus, in order to reduce the dose load of the medical staff when using the basic projection RAO-cranial, appropriate training and accumulated experience based on training are again needed, in order to reduce the maximum duration of the procedure. It is also highly recommended that during work, the medical personnel be protected with adequate equipment of not less than 0.5 $\mathrm{mm}$ lead equivalent. Most appropriate is the use of lead-rubber apron, because the gonads receive the highest dose. In addition, they are the most susceptible organs in the human body to ionizing radiation. The head receives lower dose, but the number and the duration of the procedures, performed by the medical 
staff increase the accumulated dose. For this reason, it is advisable to wear lead-shielded collars, goggles, and hats to protect head and neck. The feet also receive a significant dose load, but the limbs are among the least radiation-sensitive structures in the human body, so they shouldn't be protected as well as the rest of the body. With regard to the position of the patient table during the procedure under $x$-ray guidance, the results show, especially for the basic RAO-cranial projection, the highest dose load at the highest table position (due to the largest number of high values), and the lowest dose load at the lowest position of the patient table (due to the largest number of low values). In this sense, when working with a basic RAO-cranial projection, it is advisable to use the lowest possible position of the patient table. When using an LAO-cranial projection as basic projection, the dose in the point "head" is almost the same for all three table positions. And due to the fact that the feet are the least sensitive to $\mathrm{X}$-rays, the conclusion can be made according to the radiation at the measurement point "gonads".

At this point, the lowest radiation is again observed at for the lowest position of the patient table.

When working in Pure Cranial as basic projection, and taking into account the above considerations and comparing only the dose values in the measurement point "gonads", a minimum dose load would be achieved in the zero position of the patient mass.

\section{Recommendations}

From the conclusions made so far, we could summarize the following recommendations to reduce the dose load of medical staff performing LAD stenting under X-ray guidance:

1) A minimum time must be achieved to perform a quality procedure, especially when working under $\mathrm{X}$-ray guidance in radiographic mode;

2) A patient table position should be used that is as comfortable as possible for the principal interventional cardiologist. For the RAO- and LAO-cranial as basic projections, this is as close as possible to the lowest position of the patient table and for Pure Cranial-as close as possible to the zero position;

3) Individual protective equipment must be used during work-apron, collar, goggles and hat which have lead equivalent not less than $0.5 \mathrm{~mm}$.

Compliance with these recommendations would result in a reduction in the $\mathrm{x}$-ray dose obtained from scattered radiation during the angiographic LAD stenting procedure.

\section{Acknowledgements}

Special thanks to Natasha Ivanova from the Medical University, Varna for the data provided, on the basis of which we conducted this study.

Special thanks also to the editors of the magazine for their help in printing the article. 


\section{Conflicts of Interest}

The author declares no conflicts of interest regarding the publication of this paper.

\section{References}

[1] Иванова, Н. (2013) Естествен радиационен фон, II Национален конгрес по физически науки и 41-ва Национална конференция по въпросите на обучението по физика, Софияг, 2013.

https://sites.google.com/a/bgphysics.eu/congress2013/dokladi

[2] Ivanova, N. and Manusheva, B. (2018) Natural Radionuclides in Drinking Water. Chemistry: Bulgarian Journal of Science Education, 27, 460-465. http://khimiya.org/

[3] Ivanova N. (2008) 110th Anniversary of the Astrophysisist Fritz Zwicky. Bulgarian Astronomical Journal, 10, 135-145.

[4] Иванова, Н. and Ненкова, П. (2012) Макс фон Лауе-нобелов лауреат с безупречна репутация и мъжествено поведение в годините на нацизма. Сборник с доклади от 40-та Юбилейна Национална конференция по въпросите на обучението по физика, Габрово, 325-328.

[5] Hofman, J.A.M. (2010) The Art of Medical Imaging: Philips and the Evolution of Medical X-Ray Technology. Clinical Applications, MEDICAMUNDI 54/1.

http://incenter.medical.philips.com/doclib/enc/fetch/2000/4504/577242/577256/588 821/5050628/5313460/6391861/\%5b04\%5d_MM_54-1_Hofman.pdf\%3fnodeid\%3d6 391873\%26vernum\%3d-2

[6] PHILIPS (n.d.) History of X-Ray.

https://www.philips.com/consumerfiles/newscenter/main/shared/assets/Downloada blefile/FACT_SHEET_X-ray_history.pdf

[7] Иванова, Н. (2011) Д. Гроздев “Ядрени централи-аварии и последствия”, Сборник с доклади от XXXIX национална конференция по въпросите на обучението по физика, 150-153.

[8] Ivanova, N. and Ivanova, S. (2016) Radiation Incident in "Polimeri” Devnya, Actions and Safety Measures: A Case Study. Ecology \& Safety, 10, 515-523. https://www.scientific-publications.net/en/issue/1000017/

[9] Ivanova, N. and Ivanova S. (2017) Calculation of the Expected Dose for a Radiation Incident Involving the Theft of Radioactive Sources. RAD Conference Proceedings, 2, 80-84. http://www.rad-proceedings.org https://doi.org/10.21175/RadProc.2017.17

[10] Белчева, Г. and Иванова, Н. (2015) Приложение на лазерите в рефрактивната корекция на зрението и диабетната ретинопатия. Сборник с доклади от XXXII колоквиум “Физиката в опазването на човека и околната среда" на тема “Светлината в медицината. 407-412.

[11] Ivanova, N. and Ivanova, S. (2016) Estimation of Doses from Patients Undergoing Treatments Whit Radiopharmaceuticals. RAD Conference Proceeding, 1, 33-35.

http://www.rad-proceedings.org/ https://doi.org/10.21175/RadProc.2016.09

[12] Иванова, Н., Иванова, С. and Чаушев, Б. (2016) Качество на образа при рентгеновата диагностика. Proceeding of 3rd National Congress on Physical Sciences, Sofia, 29 September-2 October 2016, 1-6.

http://upb.phys.uni-sofia.bg/conference/3kongres/disk/html/Cont08.htm

[13] Иванова, Н. and Иванова, С. (2014) Обновяване на медицинската рентгенова 
апаратура във Варненска, Шуменска и Добричка област. Сборник с доклади от 42-ра Национална конференция по въпросите на обучението по физика, 118-122, Стара Загора, 2014 г., Издателство “Херон Прес” ООД, София 2014.

[14] Ivanova, N. (2016) Ionizing Radiation in the Education in Medicine. BgNS Transactions, 21, 74-78. http://bgns-transactions.org/journals/volume-21-1/

[15] Иванова, Н. and Илиева, Детелина (2020) Студенти медици и ядрената физика. Физика: Методология на обучението, 8, 80-87.

[16] Иванова, Н. (2018) Радиационна защита в медицината-професионална Квалификация. Сборник доклади от научна конференция "Радиационната безопасност в съвременния свят”. Електронно издание, 21-26.

[17] Natasha, I. (2020) Interesting Moments of the Work during Specialized Training of Staff Working with Ionizing Radiations. Journal of Human Resource and Sustainability Studies, 8, 266-273. https://doi.org/10.4236/jhrss.2020.83015

[18] Иванова, Н.И. (2020) Йонизиращи лъчения и безопасна работа с тях. учебник, издателство на Медицински университет Варна.

[19] Иванова, Н.И. (2020) Рентгенова система тип “С-рамо. Дозово натоварване на персонал и пациенти. монография, издателство на Медицински университет, Варна.

[20] Иванова, Н.И. (2020) Ангиографска рентгенова система с G-рамо Дозово натоварване на персонал. монография, издателство на Медицински университет, Варна.

[21] Natasha, I. (2020) Radiation Protection of a Patient Undergoing an Orthopedic Procedure by Using a Mobile C-Arm X-Ray System. International Journal of Medical Physics, Clinical Engineering and Radiation Oncology, 9, 41-156.

[22] Natasha, I., Javor, I., Marin, M. and Miroslav, P. (2021) Dose Load during Orthopedic Procedures. Open Access Library Journal, 8, e7107.

https://www.scirp.org/pdf/oalibj_2021022012115970.pdf

[23] Natasha, I., Javor, I., Miroslav, P. and Marin, M. (2021) Comparison of Dose Rate When Working with a C-Arm X-Ray System. Scripta Scientifica Medica, Scientific Online Resource System, Original Articles. https://journals.mu-varna.bg/index.php/ssm/article/view/7154/6820

[24] Natasha, I., Javor, I., Bistra, M., Ismet, T., Hrisimir, T. and Nikolai, A. (2020) Dose Load to the Interventional Cardiologist for Different Positions of the Patient Table-First Results. RAD Conference Proceedings, 4, 18-22.

http://www.rad-proceedings.org http://doi.org/10.21175/RadProc.2020.04

[25] Natasha, I., Javor, I., Bistra, M., Ismet, T., Hrisimir, T. and Nikolai, A. (2020) Dose Load to Different Parts of the Body of the Interventional Cardiologist-First Results. RAD Conference Proceedings, 4, 55-59. http://www.rad-proceedings.org http://doi.org/10.21175/RadProc.2020.11

[26] Natasha, I. and Javor, I. (2021) Dose Load during Angiographic Procedures. Open Access Library Journal, 8, e7109. https://www.scirp.org/pdf/oalibj_2021022012125888.pdf

[27] Guo, C., Xiong, Z., Vijayan, S., Rudin, S. and Bednarek, D.R. (2018) Developing a Database of 3-D Scattered Radiation Distributions for a c-Arm Fluoroscope as a Function of Exposure Parameters and Phantom. SPIE Medical Imaging 2018, Houston, 9 March 2018, Article ID: 1057360. https://doi.org/10.1117/12.2293788

[28] Alnewaini, Z., Langer, E., Schaber, P., David, M., Kretz, D., Steil, V. and Hesser, J. 
(2017) Real-Time, Ray Casting-Based Scatter Dose Estimation for C-Arm X-Ray System. Journal of Applied Clinical Medical Physics, 18, 144-153.

https://doi.org/10.1002/acm2.12036

[29] Sadick, V., Reed, W., Collins, L, Sadick, N., Heard, R. and Robinson, J. (2010) Impact of Biplane versus Single-Plane Imaging on Radiation Dose, Contrast Load and Procedural Time in Coronary Angioplasty. The British Journal of Radiology, 83, 379-394. https://doi.org/10.1259/bjr/21696839

https://www.ncbi.nlm.nih.gov/pmc/articles/PMC3473578/

[30] Mavrikou, I., Kottou, S., Tsapaki, V. and Neofotistou, V. (2008) High patient Doses in Interventional Cardiology Due to Physicians' Negligence: How Can They Be Prevented? Radiation Protection Dosimetry, 129, 67-70.

https://pubmed.ncbi.nlm.nih.gov/18337290/

https://doi.org/10.1093/rpd/ncn005 